\title{
Does Pulse Rate Influence Tomato Likeliness?
}

\author{
Muhammad Imran QAM* \\ Institute of Molecular Biology and Biotechnology, Pakistan \\ *Corresponding author: Muhammad Imran QAM, Institute of Molecular Biology and Biotechnology, Pakistan
}

$\overline{\text { ARTICLE INFO }}$ ABSTRACT

Received: 幽 January 31, 2019

Published: 蔧 March 06, 2019

Citation: Muhammad Imran QAM. Does Pulse Rate Influence Tomato Likeliness?. Biomed J Sci \& Tech Res 15(4)-2019. BJSTR. MS.ID.002722.
Pulse signifies the tangible arterial inspection of the heartbeat by proficient fingerextremity. The main goal of this recent research was to co-relate regular pulse rate with tomato likeliness. Then, we recorded the pulse rate of different students with the help of Heart rate monitor and by common method like from patient's wrist. Statistical analysis was achieved by applying the M state software. T-test was used to evaluate the result.

Keywords: Tomato Likeliness; Pulse Rate; Arterial Inspection; Heartbeat

\section{Introduction}

In medical science, a pulse signifies the tangible arterial inspection of the heartbeat by proficient finger-extremity. The beat could be palpated in any location that permits an artery to be squeezed nearby the exterior of the body. Pulse is equal to calculating the heart frequency. The heart rate can also be estimated by hearing to the heart beat by percussion and calculating it for a minute. The heart rate may be larger or smaller than the pulse rate relay on physiological requirement. The pulse rate can be accustomed to verifying in general heart health and strength level. A fragile pulse shows fine pulse force. It may be because of little cardiac productivity. A standard heart speed for adults ranges from 60 to 100 beats for each minute. There are diverse factors that can manipulate heart rate, such as age, being a smoker one, strength and action levels, temperature of air, feelings, size of the body, medications. Usually a lesser heart rate in relax position implies more well-organized heart function and improved cardiovascular strength.

Eating some foods or drinking some type of beverages, could cause your heartbeat to increase above your regular resting heart rate. Every individual has dissimilar blood group. So, for this project, we had assembled various data about the association of tomato likeliness with blood group and pulse rate from diverse people. According to our study work, different scholars have dissimilar blood groups and different pulse rates. Then we gathered the data about their link with tomato. So, individual having blood group B positive and 0 positive were most attracted to tomatoes. While other people of different blood groups had very little likeliness to tomatoes. We also concluded that pulse rate is not affected by eating tomatoes. The main goal of this recent research was to corelate regular pulse rate with tomato likeliness.

\section{Materials and Methods}

An overall of 220 subjects participated in this project. The subjects were scholars of Bahauddin Zakariya University Multan, Pakistan. Then, we recorded the pulse rate of diverse scholars. Mainly ECG sensors are used, that determine the electrical action of heart over a period. It is detected by electrode attached to the exterior of skin and recorded by a machine outside to body. The common way of checking pulse is to place two fingers between the bones or within the patient's wrist. Then, push it softly next to the pulse and then note any irregularity in force and beat or regularity. In this way, we measured pulse rate of different students.

This project was designed to correlate pulse rate with tomato likeliness.

\section{Statistical Analysis}

Statistical analysis was achieved by applying the $M$ state software. t-Test was used to evaluate the result. $\mathrm{P}<0.05$ was regarded as a most significant value.

\section{Result}

Table 1 From this project, we concluded that pulse rate has no influence on person's life. For instance, we perceive that pulse rate affected when we saw lizard and if we had temperature or our 
health is distressed then pulse rate would be exaggerated. About 202 students took part in this investigation and we observe different people had diverse pulse rates. Most of the people who said 'Yes' is 155.04 with STDEVA 884.25. While other people who said 'No' is 78.60 with STDEVA 16.02. And T-test gave value of 0.329 .So, from this analysis it is observed that result is non-significant because value of $\mathrm{P}$ is greater than 0.05 .

Table 1: Relationship of normal pulse rate with tomato likeliness is given in the below table.

\begin{tabular}{|c|c|}
\hline Yes & No \\
\hline Avg. \pm STDEVA & Avg. \pm STDEVA \\
\hline $155.06 \pm 884.25$ & $78.605 \div 16.027$ \\
\hline $\boldsymbol{t}$-Test $: 0.329$ & \\
\hline $\mathrm{P}=0.329$ & \\
\hline $\mathrm{P}<0.05$ & \\
\hline & \\
\hline
\end{tabular}

\section{Conclusion}

We concluded from this survey that person or individual having high pulse rate had no effect on tomato likeliness, while one with low pulse rate had effect on tomato likeliness.

\section{ISSN: 2574-1241}

DOI: 10.26717/BJSTR.2019.15.002722

Muhammad Imran QAM. Biomed J Sci \& Tech Res

CC (P) This work is licensed under Creative

Submission Link: https://biomedres.us/submit-manuscript.php

\section{References}

1. Eenglish MP (1976) Nails and fungi. Br J Dermatol 94(6): 697-701.

2. Gentles JC, Evans EG (1970) Infection of the feet and nails with Hendersonula toruloidea. Sabouraudia: J Med Vet Mycol 8(1): 72-75.

3. Qadir MI, Javid A (2018) Awareness about Crohn's Disease in biotechnology students. Glo Adv Res J Med Medical Sci 7(3): 62-64.

4. Qadir MI, Saleem A (2018) Awareness about ischemic heart disease in university biotechnology students. Glo Adv Res J Med Medical Sci 7(3): 059-061.

5. Qadir MI, Ishfaq S (2018) Awareness about hypertension in biology students. Int J Mod Pharma Res 7(2): 8-10.

6. Qadir MI, Mehwish (2018) Awareness about psoriasis disease. Int J Mod Pharma Res 7(2): 17-18.

7. Qadir MI, Shahzad R (2018) Awareness about obesity in postgraduate students of biotechnology. Int J Mod Pharma Res 7(2): 14-16.

8. Qadir MI, Rizvi M (2018) Awareness about thalassemia in post graduate students. MOJ Lymphology \& Phlebology 2(1): 14-16.

9. Qadir MI, Ghalia BA (2018) Awareness survey about colorectal cancer in students of M. Phil Biotechnology at Bahauddin Zakariya University, Multan, Pakistan. Nov Appro in Can Study 1(3): NACS000514.

10. Qadir MI, Saba G (2018) Awareness about intestinal cancer in university student. Nov Appro in Can Study 1(3): NACS.000515.

$\begin{array}{ll}\text { BIOMEDICAL } & \text { Assets of Publishing with us } \\ \text { RESEARCHES } & \text { - Global archiving of articles } \\ & \text { - Immediate, unrestricted online access } \\ & \text { - Rigorous Peer Review Process } \\ \end{array}$

